Roni Faslah: Pemanfaatan Internet Dalam Pengembangan Konsep IPS dan Implikasinya Terhadap Pembelajaran Bermakna (Meaningful Learning)

\title{
PEMANFAATAN INTERNET DALAM PENGEMBANGAN KONSEP IPS DAN IMPLIKASINYA TERHADAP PEMBELAJARAN BERMAKNA
}

\section{Roni Faslah*}

\begin{abstract}
Information Communication Technology has a significant impact on learning. ICT as a tool can be fully utilized in the concept of learning. Moreover, if the concept of learning in abstract form. The Internet can be a tool to develop concepts and create meaningful social studies learning. Learning resources are acquired and managed by advances in technology it is possible for students to learn the concepts of social science to be meaningful (meaningful), because with photographic images, documentary, animated or information presented to be more complete and detailed that it easily understood by students. Complex process can be simplified, faster process can be slowed, slow process can be accelerated without reducing substances subject matter. ICT can bring real experience into the classroom without having the students leave the classroom, so the real experience is in addition to creating meaningful learning will also develop social skills.
\end{abstract}

Keywords: ICT, internet, social studies, meaningful learning

\section{PENDAHULUAN}

Information Communication of Technology (ICT) atau Teknologi Informasi dan Komunikasi (TIK) mengalami perkembangan yang pesat. Kemajuan suatu negara salah satunya diukur dari perkembangan TIK yang dimiliki. Beberapa indikator TIK diantaranya adalah infrastruktur dan akses TIK, penggunaan dan akses TIK oleh rumah tangga dan individu, bisnis dan sektor perdagangan alat-alat TIK. Menteri Komunikasi dan Informasi Mohammad Nuh mengatakan bahwa Makro Indikator TIK digunakan untuk mengetahui peranan TIK terhadap pertumbuhan ekonomi, yang bisa

\footnotetext{
* Roni Faslah. Dosen Fakultas Ekonomi Universitas Negeri Jakarta.
}

dijadikan pegangan bagi para steakholders dalam menentukan arah kebijakan bisnis mereka ke depan (Yanuar, 2008).

UNESCO Asia dalam artikel Developing and Using Indicators of ICT in Education mengatakan bahwa cukup penting untuk menguji indikator bahwa TIK tidak hanya digunakan sebagai alat dasar operasional tetapi juga sebagai alat komunikasi dalam rangka mengembangkan kreativitas, interaksi, collaborative learning (belajar kelompok), berpikir kritis dan memecahkan masalah. Berdasarkan penelitian yang dilakukan institusi luar negeri, menempatkan Indonesia di peringkat terbawah dalam kemajuan TIK. Abdullah Alkaff staff khusus Menteri Komunikasi dan Informasi 
Roni Faslah: Pemanfaatan Internet Dalam Pengembangan Konsep IPS dan Implikasinya Terhadap Pembelajaran Bermakna (Meaningful Learning)

mengatakan bahwa selama ini indikator TIK Indonesia banyak dilakukan institusi asing yang kerap kali bias dan tidak akurat (jurnalnasional.com). Sehingga perlu adanya evaluasi ulang terhadap hasil penelitian tersebut.

Hasil survey yang dilakukan oleh Yahoo pada tahun 2008, oleh TNS Indonesia Wilayah Jabodetabek, Surabaya, Bandung, Medan, Semarang, Palembang dan Makasar menunjukkan bahwa pengguna internet Indonesia tumbuh sebesar $1.150 \%$, penetrasi pengguna internet telah mencapai $12,5 \%$ dari populasi, kalangan remaja usia 15-19 tahun mendominasi pengguna internet di Indonesia (64\%). Dominasi penggunaan layanan online: e-mail : $59 \%$, instant messaging (59\%), Social Networking 58\%. Selain itu, pengguna juga menggunkan: Search engine $56 \%$, mengakses berita online $47 \%$, Menulis blog $36 \%$, dan memainkan game online $35 \%$.

Dengan adanya internet, pihak akademisi merupakan salah satu pihak yang diuntungkan. Berbagai referensi, jurnal, maupun hasil penelitian yang dipublikasikan melalui internet tersedia dalam jumlah yang berlimpah. Dari sejumlah studi yang telah dilakukan, menunjukkan bahwa internet memang bisa dipergunakan sebagai media pembelajaran, seperti studi yang telah dilakukan oleh Center for Applied Special Technology (CAST) pada tahun 1996. Hal serupa juga diungkapkan Rahardjo (2002) sebagaimana dikutip di situs, bahwa manfaat internet bagi pendidikan adalah dapat menjadi akses kepada sumber informasi, akses kepada nara sumber, dan sebagai media kerjasama (pustekkom.depdiknas.go.id). Dengan dijadikannya internet sebagai media belajar diharapkan mampu mendongkrak hasil belajar siswa. Igrabia dan Tan (1997) dalam Impacts of Internet Usage on Student's Academic Performance (CGPA) sebagaimana dikutip dari Awais et al. (2007) menyebutkan bahwa penggunaan internet di kalangan mahasiswa di berbagai universitas termasuk frekuensi dan intensitas penggunaan internet berkorelasi signifikan dengan prestasi siswa.

Selain itu penggunaan media belajar menurut Ibrahim (1982:12) sebagaimana dikutip dalam Dubatar (2008) salah satunya mampu membangkitkan minat atau motivasi dan mengaktifkan siswa dalam belajar. Dalam kaitannya internet sebagai media belajar maka pengaruh terhadap motivasi belajar cukup signifikan karena di dalamnya ada kegiatan mencari sumber belajar yang relevan, mendownload data, mempelajari dan menggunakannya untuk kegiatan akademik tertentu.

William E. Jaber dalam penelitiannya yang berjudul $A$ Survey of Factors Which Influence Teachers' Use of Computer-based Technology menunjukkan bahwa tinggi rendahnya intensitas penggunaan komputer dalam pembelajaran sangat tergantung dari faktor kemudahan akses dan ketersediaan fasilitas kompute di kelas. Survei ini dilakukan terhadap guru pada dua kelompok sekolah daerah pedesaan. Salah satunya di Virginia Barat selatan dan 
Roni Faslah: Pemanfaatan Internet Dalam Pengembangan Konsep IPS dan Implikasinya Terhadap Pembelajaran Bermakna (Meaningful Learning)

Virginia barat daya. Survei ini menemukan bahwa akses komputer di kelas mempengaruhi frekuensi yang digunakan untuk beberapa kegiatan pembelajaran. Kurangnya akses Internet dan peralatan komputer yang usang menghasilkan pengaruh yang negatif terhadap intensitas dalam guru menggunakan teknologi berbasis komputer di kelas.

Ini berarti bahwa kemampuan siswa dalam menerima pembelajaran bebasis komputer dipengaruhi oleh faktor ketersediaan dan kemampuan dalam menggunakan komputer, lingkungan sosial dan karakteristik pendidik. Komputer tidak akan banyak berarti jika dalam pemanfaatanya tidak disertai dengan kemampuan yang memadai. Di samping itu ketersediaan dan kemutakhiran teknologi komputer serta kemudahan akses juga menjadi faktor penentu optimalisasi pemanfaatan teknologi informasi dan komunikasi dalam proses pembelajaran.

\section{PEMANFAATAN INTERNET}

Davis pada tahun 1989 menyusun Technology Acceptance Model (TAM) untuk memahami perilaku penerimaan teknologi. Teori ini berasal dari sebuah teori induk (grand-theory) di bidang kajian keyakinan, sikap dan perilaku (belief, attitude and behavior) yang diformulasikan oleh Fishbein \& Ajzen (1975) dengan nama Theory of Reasoned Action (TRA).

Theory Reasoned Action pertama kali dicetuskan oleh Ajzen pada tahun 1980 (Jogiyanto, 2007). Teori ini disusun menggunakan asumsi dasar bahwa manusia berperilaku dengan cara yang sadar dan mempertimbangkan segala informasi yang tersedia. Dalam TRA ini, Ajzen (1980) menyatakan bahwa niat seseorang untuk melakukan suatu perilaku menentukan akan dilakukan atau tidak dilakukannya perilaku tersebut. Lebih lanjut, Ajzen mengemukakan bahwa niat melakukan atau tidak melakukan perilaku tertentu dipengaruhi oleh dua penentu dasar, yang pertama berhubungan dengan sikap (attitude towards behavior) dan yang lain berhubungan dengan pengaruh sosial yaitu norma subjektif (subjective norms). Dalam upaya mengungkapkan pengaruh sikap dan norma subjektif terhadap niat untuk dilakukan atau tidak dilakukannya perilaku, Ajzen melengkapi TRA ini dengan keyakinan (beliefs). Dikemukakannya bahwa sikap berasal dari keyakinan terhadap perilaku (behavioral beliefs), sedangkan Norma subjektif berasal dari keyakinan normatif (normative beliefs).

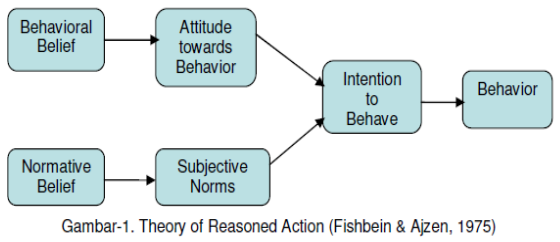

Technology Acceptance Model (TAM) adalah model yang disusun oleh Davis (1986) untuk menjelaskan penerimaan teknologi yang akan digunakan oleh pengguna teknologi. Dalam memformulasikan TAM, Davis menggunakan TRA sebagai grand theorynya namun tidak mengakomodasi semua komponen 
Roni Faslah: Pemanfaatan Internet Dalam Pengembangan Konsep IPS dan Implikasinya Terhadap Pembelajaran Bermakna (Meaningful Learning)

teori TRA seperti yang tergambarkan dalam Gambar-1. Davis hanya memanfaatkan komponen 'Belief' dan Attitude' saja, sedangkan Normative Belief dan Subjective Norms tidak digunakannya. Secara skematik teori TAM tergambarkan dalam Gambar 3.

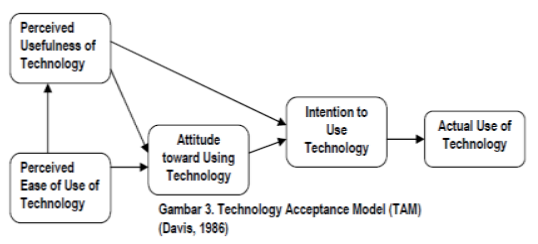

Menurut Davis perilaku menggunakan IT diawali oleh adanya persepsi mengenai manfaat (usefulness) dan persepsi mengenai kemudahan menggunakan IT (ease of use). Kedua komponen ini bila dikaitkan dengan TRA adalah bagian dari Belief. Davis mendefinisikan persepsi mengenai kegunaan (usefulness) ini berdasarkan definisi dari kata useful yaitu capable of being used advantageously, atau dapat digunakan untuk tujuan yang menguntungkan. Persepsi terhadap usefulness adalah manfaat yang diyakini individu dapat diperolehnya apabila menggunakan IT. Dalam konteks organisasi, kegunaan ini tentu saja dikaitkan dengan peningkatan kinerja individu yang secara langsung atau tidak langsung berdampak pada kesempatan memperoleh keuntungankeuntungan baik yang bersifat fisik atau materi maupun non materi.

Agak berbeda dengan persepsi individu terhadap kegunaan IT ini, variabel lain yang dikemukakan Davis mempengaruhi

kecenderungan

individu menggunakan IT adalah persepsi terhadap kemudahan dalam menggunakan IT. Kemudahan (ease) bermakna tanpa kesulitan atau terbebaskan dari kesulitan atau tidak perlu berusaha keras. Dengan demikian persepsi mengenai kemudahan menggunakan ini merujuk pada keyakinan individu bahwa sistem IT yang akan digunakan tidak merepotkan atau tidak membutuhkan usaha yang besar, pada saat digunakan.

Persepsi terhadap manfaat IT (Perceived usefulness) dan persepsi terhadap kemudahan penggunaan IT (Perceived ease of use) mempengaruhi sikap (Attitude) individu terhadap penggunaan IT, yang selanjutnya akan menentukan apakah orang berniat untuk menggunakan IT (Intention). Niat untuk menggunakan IT akan menentukan apakah orang akan menggunakan IT (Behavior). Dalam TAM, Davis (1986) menemukan bahwa persepsi terhadap manfaat IT juga mempengaruhi persepsi kemudahan penggunaan IT tetapi tidak berlaku sebaliknya. Dengan demikian, selama individu merasa bahwa IT bermanfaat dalam tugas-tugasnya, ia akan berniat untuk menggunakannya terlepas apakah IT itu mudah atau tidak mudah digunakan.

\section{PENGEMBANGAN KONSEP IPS MELALUI PEMANFAATAN INTERNET}

Pembelajaran IPS harus berperspektif global. Perpektif global merupakan pandangan dimana guru dan murid secara bersama-sama 
Roni Faslah: Pemanfaatan Internet Dalam Pengembangan Konsep IPS dan Implikasinya Terhadap Pembelajaran Bermakna (Meaningful Learning)

mengembangkan perspektif dan keterampilan untuk menyelidiki suatu yang berkaitan dengan isu global. (Idealnya tercermin dalam motto " thingking globally and act locally"). Kumpulan para pakar ilmu sosial seluruh dunia yang berpusat di Amerika yang tergabung dalam wadah " National Council for the Sosial Studies " ( NCSS) pada tahun 1994 memberikan sejumlah rambu-rambu kapan pembelajaran IPS akan menjadi sangat kuat (powerful) apabila; 1) Terasa bermakna, yaitu bila siswa mampu menghubungkan pengetahuan, ketrampilan dan sikap yang dipelajari di sekolah dan luar sekolah, penyampaian bahan ajar ditujukan pada pemahaman, apresiasi dan aplikasinya dalam kehidupan.2) Pendekatan Integratif, yaitu terintegrasi pengetahuan, ketrampilan, sikap, nilai, kepercayaan dan keperbuatan nyata, 3) Berbasis nilai, khususnya menyangkut isu kontroversial yang memberikan ruang berefleksi dan bereaksi sebagai anggota masyarakat, bersikap kritis terhadap isu dan kebijakan sosial, serta menghargai perbedaan pandangan, 4) Bersifat menantang; siswa ditantang untuk mencapai tujuan pembelajaran baik secara individual maupun sebagai anggota kelompok, guru sebagai model untuk mencapai kualitas sesuai standar yang diinginkan, guru lebih menghargai pendapat siswa dengan alasan yang baik daripada pendapat asalasalan.dan 5) Bersifat aktif, memberi kesempatan berfikir dan terlibat dalam pengambilan keputusan selama pembelajaran, pengajaran harus berbasis aktivitas yang dapat ditemui di lingkungan sosial.

Pembelajaran IPS berbasis ICT adalah upaya guru dengan memanfaatkan teknologi informasi dan komunikasi dalam menyampaikan materi pelajaran kepada siswa-siswanya. Untuk itu diperlukan kreatifitas guru dalam mempersiapkan materi yang akan disampaikan kepada siswa, karena dengan menggunakan internet guru bisa mencari media atau gambar atau juga peristiwa sejarah yang dapat ditayangkan kepada siswa di dalam kelas. Salah satu bentuk pemanfaatan ICT dalam pembelajaran IPS antara lain dengan memanfaatkan Microsoft Encarta yang berisi berbagai macam ilmu pengetahuan dalam bentuk narasi, gambar, audio dan visual. Di bawah ini adalah berbagai materi pelajaran IPS yang diambil dari Microsoft Encarta :

a. Bom Atom

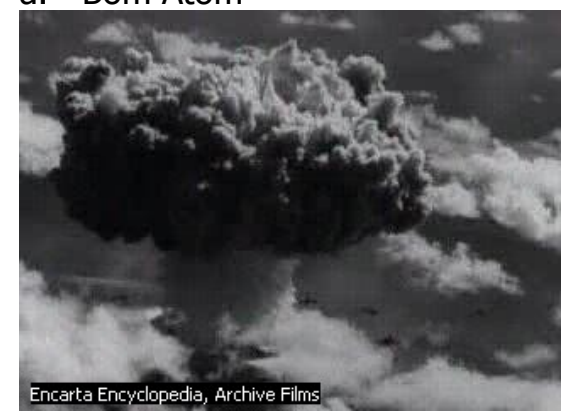

b. Letusan gunung api

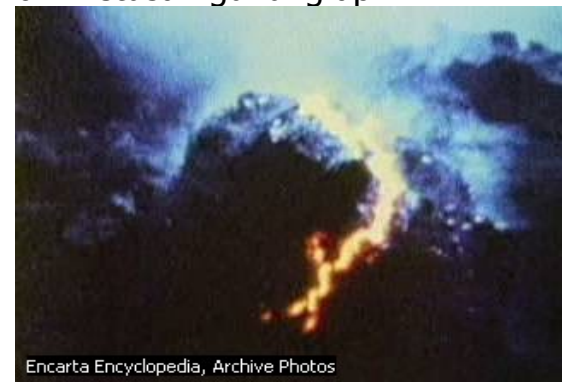


Roni Faslah: Pemanfaatan Internet Dalam Pengembangan Konsep IPS dan Implikasinya Terhadap Pembelajaran Bermakna (Meaningful Learning)

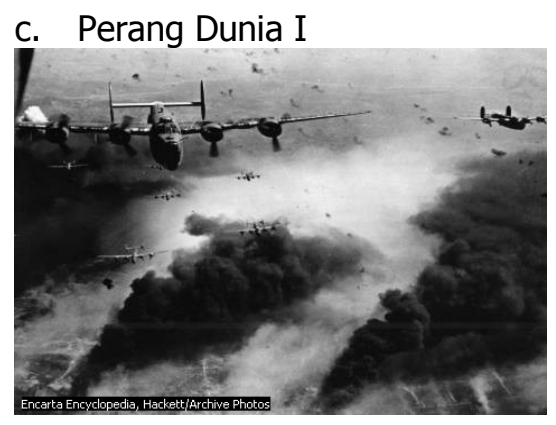

Gambar diatas adalah merupakan gambar hidup, sehingga dengan tampilan tersebut siswa menjadi respons dan bersemangant dalam mempelajari ilmu pengetahuan sosial.

Berikut ini berbagai contoh yang dipergunakan dalam pembelajaran e-lerning untuk pendidikan IPS dan Sosiologi :

1. Jurnal Teknologi pendidikan

$$
\text { JURNAL }
$$

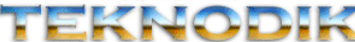

Wahana Komunikasi Pengembangan dan Pendayagunaan Teknologi Pendidikar

2. Jurnal Ekonomi Rakyat

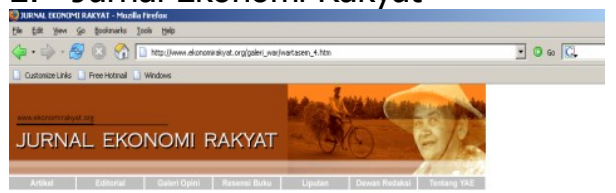

3. Jurnal Agro Ekonomi Jurnal Agro Ekonomi

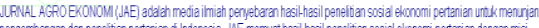

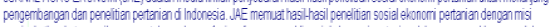

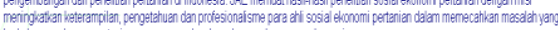

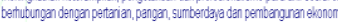

4. Jurnal social-politika

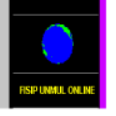

Jurnal Sosial-Politik Joumal of Secial and Political Sciences)

5. Jurnal Sosiologi and cultural

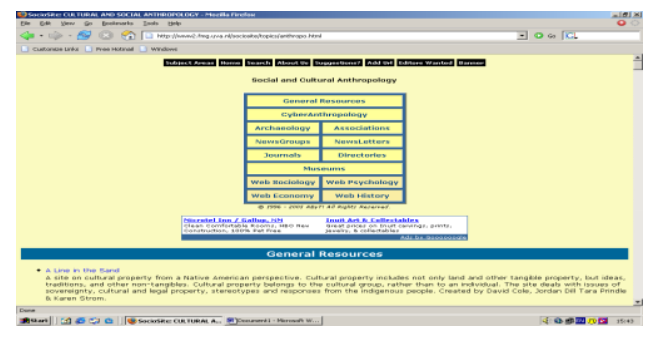

6. Jurnal American Atropological association

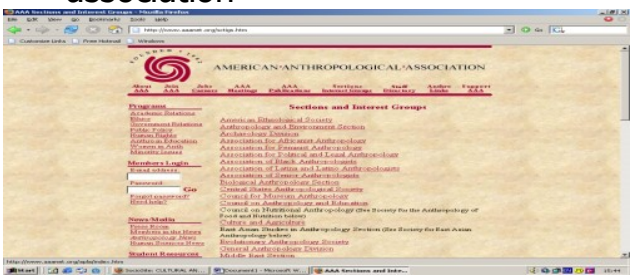

\section{PEMBELAJARAN BERMAKNA (MEANINGUL LEARNING)}

Pembelajaran menjadi bermakna ketika siswa dapat menghubungkan satu konsep dengan konsep lainnya. Proses penghubungan antar konsep ini tergantung dari banyaknya pengalaman konsep yang dimiliki siswa. Siswa akan mudah memahami sebuah konsep jika siswa dapat mengalami, merasakan dan konsep tersebut tidak abstrak.

Teori pembelajaran Ausubel merupakan salah satu dari sekian banyaknya teori pembelajaran yang menjadi dasar dalam cooperative learning. David Ausubel adalah seorang ahli psikologi pendidikan. Menurut Ausubel bahan subjek yang dipelajari siswa mestilah "bermakna" (meaningfull). Pembelajaran bermakna merupakan suatu proses mengaitkan informasi baru pada konsep-konsep relevan yang terdapat dalam struktur kognitif seseorang. Struktur kognitif 
Roni Faslah: Pemanfaatan Internet Dalam Pengembangan Konsep IPS dan Implikasinya Terhadap Pembelajaran Bermakna (Meaningful Learning)

ialah fakta-fakta, konsep-konsep, dan generalisasi-generalisasi yang telah dipelajari dan diingat siswa.

Pembelajaran bermakna adalah suatu proses pembelajaran di mana informasi baru dihubungkan dengan struktur pengertian yang sudah dimiliki seseorang yang sedang melalui pembelajaran. Pembelajaran bermakna terjadi apabila siswa boleh menghubungkan fenomena baru ke dalam struktur pengetahuan mereka. Artinya, bahan subjek itu mesti sesuai dengan keterampilan siswa dan mesti relevan dengan struktur kognitif yang dimiliki siswa. Oleh karena itu, subjek mesti dikaitkan dengan konsep-konsep yang sudah dimiliki para siswa, sehingga konsep-konsep baru tersebut benar-benar terserap olehnya.

Faktor-faktor utama yang mempengaruhi belajar bermakna menurut Ausubel adalah struktur kognitif yang ada, stabilitas, dan kejelasan pengetahuan dalam suatu bidang studi tertentu dan pada waktu tertentu. Sifat-sifat struktur kognitif menentukan validitas dan kejelasan arti-arti yang timbul waktu informasi baru masuk ke dalam struktur kognitif itu; demikian pula sifat proses interaksi yang terjadi. Jika struktur kognitif itu stabil, dan diatur dengan baik, maka arti-arti yang sahih dan jelas atau tidak meragukan akan timbul dan cenderung bertahan. Tetapi sebaliknya jika struktur kognitif itu tidak stabil, meragukan, dan tidak teratur, maka struktur kognitif itu cenderung menghambat relajar. Menurut Ausubel, seseorang belajar dengan mengasosiasikan fenomena baru ke dalam sekema yang telah ia punya.
Dalam proses itu seseorang dapat memperkembangkan skema yang ada atau dapat mengubahnya. Dalam proses belajar ini siswa mengonstruksi apa yang ia pelajari sendiri.

Internet dapat menjadi alat untuk mengembangkan konsepkonsep IPS dan menciptakan pembelajaran bermakna. Sebagai ilustrasi konsep sungai, sungai adalah aliran air alami yang memiliki debit air yang cukup dan mengalir ke laut. Siswa akan lebih memahami konsep sungai jika siswa dihadapkan langsung kepada sungai. Tetapi ini tidak memungkinkan karena memerlukan waktu yang cukup untuk dapat mengamati karakteristik sungai sampai aliran menuju ke laut.

Tetapi dengan bantuan internet dan kemajuan ICT, guru dapat me-download film atau video tentang sungai misalnya sungai citarum.

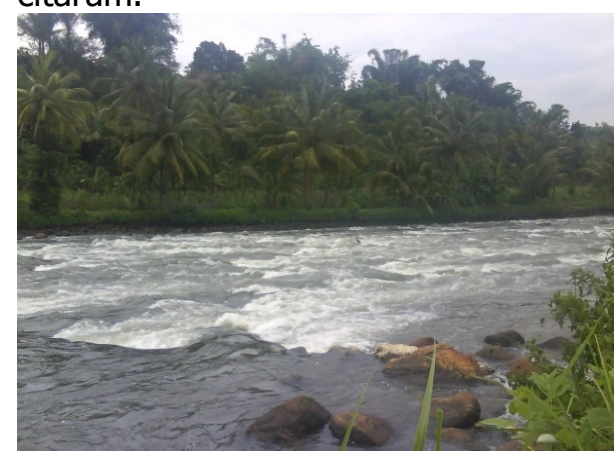

Tetapi dalam film tersebut terlihat tumpukan sampah di beberapa ruas aliran sungai yang kemudian menimbulkan luapan air dan terjadilah banjir. Melihat kejadian ini siswa akan menghubungkan beberapa konsep selain sungai yaitu konsep sampah dan konsep banjir serta konsep perilaku masyarakat. Ketika siswa 
Roni Faslah: Pemanfaatan Internet Dalam Pengembangan Konsep IPS dan Implikasinya Terhadap Pembelajaran Bermakna (Meaningful Learning)

berhasil menghubungkan satu konsep dengan konsep lain menjadi suatu konsep yang utuh dan berarti maka telah terjadi pembelajaran bermakna.

\section{PENUTUP}

IPS sebagai salah satu Ilmu Pengetahuan yang berkaitan dengan perkembangan kehidupan manusia baik dari segi ekonomi, hubungan sosial, budaya, sejarah, hukum maupun interaksinya dengan lingkungan alam sangat erat kaitannya dengan tingkat peradaban manusia, termasuk teknologi masa kini. Semua aspek kehidupan manusia itu adalah obyek kajian IPS. Untuk itu agar dapat memperjelas materi pembelajaran yang demikian luas dan senantiasa mengalami perkembangan ini, maka teknologi informasi dan komunikasi (TIK) yang berkembang sekarang sangat mendukung.

Berbagai materi yang berkaitan dengan sejarah masa lalu akan lebih konkrit dan mudah dipahami apabila disampaikan oleh guru dengan gambar-gambar foto, film dokumenter, atau animasi seperti hewan purbakala, animasi ruangruang dalam piramide Mesir dan sebagainya. Kondisi cuaca dan iklim akan lebih menarik apabila siswa disuguhi film cuaca ekstrim yang terjadi dibeberapa belahan dunia, sehingga siswa mengetahui perubahan iklim yang sebenarnya. Peta dan Interpretasi Foto Udara akan jauh lebih mengena apabila siswa ditunjukkan dengan hasil foto satelit seperti yang ada dalam internet (Google Earth) atau Wikipedia dari pada hanya sekedar hasil foto-foto udara biasa.

Sumber belajar yang diperoleh dan dikelola denggan kemajuan teknologi sangat memungkinkan bagi siswa untuk mempelajari konsepkonsep IPS menjadi bermakna (meaningful), karena dengan gambargambar foto, film dokumenter, atau animasi informasi yang disampaikan menjadi lebih lengkap dan rinci sehingga mudah dipahami oleh siswa. Proses yang kompleks dapat disederhanakan, proses yang cepat dapat diperlambat, proses yang lambat dapat dipercepat tanpa mengurangi subtansi materi pelajaran. ICT dapat menghadirkan pengalaman nyata ke dalam kelas tanpa harus siswa meinggalkan kelas, sehingga pengalaman nyata ini selain menciptakan kebermaknaan belajar juga akan membentuk keterampilan sosial.

\section{DAFTAR PUSTAKA}

Adel Ben Youssef dan Mounir Dahmani. The Impact of ICT on Student Performance in Higher Education: Direct Effects, Indirect Effects and Organisational Change. rusc vol. 5 n.o 1 (2008) | issn 1698-580x. http://rusc.uoc.edu

Admin. Situs-situs porno di search engine sebagai Top 10 Website yang paling banyak dikunjungi. http://www.amikom.info/wpcontent/uploads/a2p. cache.situssitus-porno-di-search-enginesebagai-top-10-website-yangpaling-banyak-dikunjungi.pdf 
Roni Faslah: Pemanfaatan Internet Dalam Pengembangan Konsep IPS dan Implikasinya Terhadap Pembelajaran Bermakna (Meaningful Learning)

Ajzen, I. (2005), Attitudes, Personality and Behavior, (2nd edition), Berkshire, UK: Open University Press-McGraw Hill Education

Ajzen, I., dan Fishbein, M., 1980, Understanding Attitudes and Predicting Social Behavior, Prentice-Hall, Englewood Scliffs, NJ.

Alter, Steven., 1992. Information systems : A Management Perspective. Benjamin/Cummings, California.

Ashur Harmadi dan Budi Hermana, 2005, Analisis Karakteristik Individu Dan Prilaku Pengguna Internet Banking: Reliabilitas Dan Validitas Instrumen Pengukuran. Seminar Nasional Aplikasi Teknologi Informasi 2005 (SNATI 2005) Yogyakarta, 18 Juni 2005.

Azwar Rhosyied. Analisa Pengaruh Penggunaan Internet Sebagai Media Belajar, Motivasi Belajar Dan Kreativitas Terhadap Prestasi Belajar Siswa Dengan Menggunakan Structural Equation Modeling (Studi Kasus SMAN 1 Probolinggo)

Chin, Younghwa, Kenneth A. Kozar, and Kai R.T.Todd, "The Technology Acceptance Model: Past, Present, and Future". Communication of The Association for Information System, 12, 50, hal 752-780, 1995.

Davis, F.D., 1986, 'Tecnology Acceptance Model for Empirically Testing New End-User Information Systems Theory and Results; Unpublished Doctoral Dissertation MIT.
Davis, F.D., 1989. Perceived usefulness, perceived ease of use, and user acceptance of information technology. MS Quarterly (online), Vol. 13 Iss. 3, pg. $318 . \quad h t t p: / / w w w . c b a$. hawaii.edu/chismar/ITM704/ DavisTAM 1989.pdf.

Davis, F.D., Bagozzi, R.P., and Warshaw, P.R., 1989. User acceptance of computer technology: A comparison of two theoretical models. Management Science (online), Vol. 35 Iss. 8, pg. 982.

Djamaludin Ancok. Psikologi dan Tantangan Millenium ke Tiga: Dampak Teknologi Internet Pada Kehidupan Manusia dan Pengelolaan Institusi Pendidikan Psikologi. On-line http://delouvylux.webng.com/dow nload/

kuliah_psikologi/other_archive/psik ologi_dan_teknologi_informasi.pdf

Gibaldi, J. (1998). MLA Style manual and guide to scholarly publishing. (2nd Ed). Modern Language Association of America.

Hendri Destiwanto. Remaja dan Internet. Makalah Disampaikan pada Seminar Nasional "Madu dan Racun Internet dalam Dunia Pendidikan" oleh HIMADIKSANFKIP UNS, 1 Mei 2010. On-line http://mashendri.com/wpcontent/uploads/2010/05/remajadan-internet.pdf

Hill, J. R. (1999). Teaching technology: Implementing a problem-centered, activitybased approach. Journal of Research on Computing in Education, 31, 261-279. 
Roni Faslah: Pemanfaatan Internet Dalam Pengembangan Konsep IPS dan Implikasinya Terhadap Pembelajaran Bermakna (Meaningful Learning)

http://www.alexa.com/topsites

Iman Murtono Soenhadji, Ida Astuti, dan Septi Mariani, 2005, Prediksi Keyakinan Mahasiswa Akan Manfaat Fasilitas Studentsite Dengan Pendekatan Technology Acceptance Model, Seminar Nasional Aplikasi Teknologi Informasi 2008 (SNATI 2008) Yogyakarta.

Irina Shklovski, Sara Kiesler, and Robert Kraut. The Internet and Social Interaction: A Meta-analysis and Critique of Studies, 19952003. Carnegie Mellon University. On-line http://www-

2.cs.cmu.edu/ kraut/RKraut. site.files/articles/Shklovski04InternetUseSocialRleationshipsmeta-analysis.pdf

Jogiyanto,MH. 2007.Model Kesuksesan: Sistem Teknologi Informasi. Yogyakarta: Penerbit Andi.

Kimberlee D. DeRushia. Internet Usage Among College Students And Its Impact On Depression, Social Anxiety, And Social Engagement. A Dissertation, Submitted to the School of Graduate Studies and Research in Partial Fulfillment of the Requirements for the Degree Doctor of Psychology, Indiana University of Pennsylvania May 2010

Koufaris, M., 2002, 'Applying the Technology Acceptance Model and Flow Theory to Online Consumer Behavior', dalam Information Systems Research, Vol. 13, No. 2, pp. 205-223.

Marie Groark dan Diana Oblinger.
Academic Plagiarism in the Networked Environment. Center for Applied Research Bulletin, Volume 1, Issue 1, March 2, 2001.

Novita R, Internet dan Perpustakaan. Online: http://digilib.unsri.ac.id/ download/Internet dan Perpustakaan.pdf diakses: November 2010.

Sage, S. M. (2000). A natural fit: Problem-based learning and technology standards. Learning \& Leading with Technology, 28(1), 6-12.

Tina L. Norris. Adolescent Academic Achievement, Bullying Behavior, And The Frequency of Internet Use. A dissertation submitted to Kent State University in partial fulfillment of the requirements for the degree of Doctor of Philosophy. Kent State University, May 2010.

Yasemin Gülbahar. ICT Usage In Higher Education: A Case Study On Preservice Teachers And Instructors. The Turkish Online Journal of Educational Technology - TOJET ISSN: 1303-6521 volume 7 Issue 1 Article 3. January 2008 